Recht umsetzt. EU-Richtlinien sind oftmals das Ergebnis eines Kompromisses von 27 Mitgliedstaaten. Insbesondere in einem föderalistischen Staat wie Deutschland ist die praktische Umsetzung von Richtlinien daher manchmal sehr komplex.

Seit einigen Jahren engagiere ich mich neben meinen beruflichen Tätigkeiten ehrenamtlich für die Wirtschaftsjunioren Berlin e.V., der Nachwuchsorganisation der IHK, die Mitglied im größten Verband junger Unternehmer und Führungskräfte in Deutschland sowie im weltweiten Verband Junior Chamber International (JCI) mit weltweit 200.000 Mitgliedern ist. Wir engagieren uns neben unserem Beruf gesellschaftlich, im Bereich Bildung, Existenzgründung, Umwelt und Internationales. 2010 bin ich Sprecherin des Vorstands der Wirtschaftsjunioren Berlin e.V. Durch Organisation und Moderation von politischen Veranstaltungen für junge Unternehmer(innen) im Europäischen Haus in Berlin sowie Besuche von internationalen Konferenzen lebe ich „Europa“ auch innerhalb dieses Unternehmer(innen)netzwerks.

Die Vielfalt und Entwicklung Europas ist das, was mich begeistert!

\title{
Eine Flüchtlingskarriere in Deutschland
}

\section{Jasmina Prpic \\ Vorsitzende von Anwältinnen ohne Grenzen e.V. Deutschland, Freiburg}

In der Mitte des Lebens hieß es für mich: alles zurücklassen. Ich musste beruflich wie privat neu anfangen. Ich kam als Flüchtling in ein Land, dessen Sprache ich nicht beherrschte. Ich konnte nicht einmal „Guten Tag“ sagen.

Alles hat 1990 begonnen, im Vorfeld des Krieges, der zum Zerfall Jugoslawiens, meiner alten Heimat, führen sollte. Wegen der beginnenden politischen Unruhen, auch aus Angst um meine Kinder, beschloss ich, mein Richteramt aufzugeben. Ich war seit zehn Jahren beim Amtsgericht in Banja Luka (heute Hauptstadt des serbischen Teils von Bosnien-Herzegowina) auf dem Gebiet des Zivilrechts tätig gewesen. Ich ließ mich als Rechtsanwältin nieder. Leider konnte ich diesen Beruf nur für kurze Zeit ausüben: Im April 1992 brach der Krieg aus. Ich musste mit meinem Mann und meinen zwei kleinen Töchtern fliehen und landete schließlich in Deutschland.

Als ich die nötigen Kenntnisse der deutschen Sprache erworben hatte, erhielt ich die Erlaubnis, als Rechtsbeistand für ausländisches Recht in Freiburg tätig zu sein, und arbeitete zunächst mit dem inzwischen verstorbenen, damals bekannten Fachanwalt für ausländisches Recht Dr. Konstantin Thun zusammen. Weil ich nicht in einem EU-Mitgliedstaat als Anwältin praktiziert hatte, durfte ich mich nicht als Rechtsanwältin niederlassen, was für mich ein schwerer Schlag war. Ich bin eine kämpferische Natur: Für Gerechtigkeit, insbesondere für die Gleichberechtigung von Frauen und Männern zu streiten, liegt mir im Blut.

1995 begann ich mit einem Aufbaustudium an der Rechtswissenschaftlichen Fakultät der Albert-Ludwigs-Universität Freiburg. Ich ahnte nicht, dass eine Seminararbeit mit dem Titel „Vergewaltigung als Kriegsverbrechen und Verbrechen gegen die Menschlichkeit“ mein zukünftiges Leben bestimmen würde. Schwerpunkt meiner Arbeit waren die massenhaften Vergewaltigungen in Bosnien. Insbesondere in Kriegssituationen handelt es sich bei Vergewaltigungen nie um Sexualität, sondern um Macht, Unterdrückung und Herrschaft. Vor dem
Internationalen Strafgerichtshof für das ehemalige Jugoslawien, der im Mai 1993 mit Sitz in Den Haag gegründet wurde, begann bereits im Jahr 2000 der erste Prozess, in dem Vergewaltigung als Verbrechen gegen die Menschlichkeit definiert wurde - ein historisches Ereignis. Erstmals in der Geschichte des humanitären Völkerrechts wurde sexualisierte Gewalt an Frauen nicht als unvermeidlich hingenommen, sondern als Kriegsverbrechen anerkannt und verfolgt.

Kurz darauf sprach mich Anfang 2001 Dr. Monika Hauser aus Köln an, die durch meine Seminararbeit auf mich aufmerksam geworden war. Sie ist Gründerin des Vereines medica mondiale e.V. und erhielt im Jahr 2008 für ihren Einsatz für vergewaltigte Frauen in Kriegsgebieten den Alternativen Nobelpreis (Right Livelihood Award). Sie fragte, ob ich bereit wäre, sie in den Kosovo zu begleiten, um den Frauen, die dort genauso wie Tausende von Frauen in Bosnien die schrecklichste sexualisierte Gewalt erfahren hatten und die möglicherweise als Zeuginnen vor dem Haager Tribunal aussagen sollten, zur Seite zu stehen. Ich sagte sofort zu, obwohl die Lage im Kosovo nach dem NATO-Angriff immer noch nicht sicher war. Ursprünglich war ein Jahr vorgesehen, daraus sind dann drei Jahre geworden. In dieser Zeit habe ich viel Leid gesehen und furchtbare Erfahrungen gemacht, die ich nie vergessen werde. Angeregt durch verschiedene Tagungen und Konferenzen sowohl im Kosovo als auch in Bosnien, Albanien, Kroatien, der Türkei und später dem Iran und zuletzt in Mexiko ist mir bewusst geworden, wie sehr Frauen und Frauenorganisationen juristische Hilfe brauchen. In mir wuchs der Wunsch, eine Organisation von Juristinnen verschiedener Nationalitäten zu gründen. Mein LL.M.-Studium hatte ich für diese Zeit unterbrochen, um es in besseren Zeiten fortzuführen.

Am 6. November 2007 ist dann mein Traum von damals wahr geworden: Zusammen mit elf Juristinnen gründete ich den Verein Anwältinnen ohne Grenzen e.V. Heute sind wir eine kleine Gruppe von 21 hoch motivierten, starken Frauen. Zwar sind wir nicht alle als Rechtsanwältinnen tätig, wir verstehen uns aber im weiteren Sinne als Anwältinnen von Frauen, deren Sache wir vertreten. In unserem Verein arbeiten nicht nur deutsche Juristinnen sondern Juristinnen aus der 
ganzen Welt zusammen. Unsere Mitglieder kommen aus der Türkei, Rumänien, Georgien, Frankreich, Brasilien, Palästina, Spanien, Bosnien, dem Iran und der Dominikanischen Republik - ein großer Schatz an Sprachen und Erfahrungen mit unterschiedlichen Rechtssystemen. Unser Arbeitsauftrag ist, das Übereinkommen der Vereinten Nationen zur Beseitigung jeder Form von Diskriminierung der Frau (kurz: CEDAW = Convention on the Elimination of All Forms of Discrimination Against Women) in Deutschland wie auch in den anderen Ländern unserer Mitglieder bekannt zu machen. Wir wollen der Konvention Leben einhauchen und nicht nur national, sondern international arbeiten. Durch unsere Arbeit wollen wir den Druck auf die Regierungen der jeweiligen Länder erhöhen, die Gleichberechtigung von Frauen und Männern tatsächlich durchzusetzen. In Deutschland wollen wir auch die
Interessen von Migrant(iInn)en vertreten, auf internationaler Ebene sehen wir uns als Prozessbeobachterinnen und haben die Absicht, auch in Beteiligungsverfahren Stellung zu nehmen. Unser Ziel ist es, Präzedenzfälle in der bundesverfassungsgerichtlichen Rechtsprechung zu schaffen und vor internationalen Gerichtshöfen sowie dem CEDAW-Ausschuss präsent zu sein.

Endlich ist auch eine gute Zeit für mein Aufbaustudium gekommen: Inzwischen schreibe ich an meiner LL.M.-Arbeit, und zwar mit dem Titel „25 Jahre UN CEDAW Konvention in Deutschland und ihre Anwendung - Eine Bilanz“. Nach der Abgabe meiner Arbeit im Frühling 2011 werden wir, Anwältinnen ohne Grenzen e.V., die ersten größeren Projekte in Deutschland und im Ausland beginnen. Heute kann ich stolz in fließendem Deutsch sagen: Ein großes Potenzial ist schon da.

\section{Between Orient and Occident}

\section{Siba Irsheid \\ Studentin, Freiburg i. Br.}

My name is Siba Irsheid. Born in Nablus, Palestine, I grew up in Alicante, Spain. My primary and secondary education took place in two British schools in Alicante, with students of different nationalities, cultures and religions. We communicated with each other basically in English, but also in Spanish and French. In my case, I grew with three mother languages: English, Spanish and Arabic. I also took part, during my secondary education phase, for one school year, in an interchange program, studying for that year only, in a Spanish school in the region, in order to compare the two different systems of education.

During my childhood I moved constantly between Europe and the Arab World. Every year, for a couple of months, my family and I would also visit our relatives in Palestine, living in our own skin the Israeli military occupation of the Palestinian territories. I grew up realizing that, in some countries, basic human rights were not only disrespected, but didn't seem to exist. This pushed me strongly to take the decision to study law and support organizations like Amnesty International.

When I finished my secondary education and announced to my parents that I wanted to study law, my father wasn't very happy; he wanted me to study Business Management, among other reasons, in order to help him, or follow his steps and because law, in my father's opinion, which is more or less true, ties you up to the land where you studied law in and as he always says: "the world is too big to tie yourself only to one country". However, I made him change his mind quite quickly; I convinced him that if I study law I can also be a business woman, but if I study business I cannot be a lawyer. Also that I would be a better business woman if I also knew law. Nevertheless, I was very attracted to the world of business, so I decided to do an advanced course in Management of Business and Economics, at Cambridge University. When I finished I started my law studies.

I married a German physician two years after I began my law studies and I have three sons. At that time, I kept moving between Alicante and Ebnet, Freiburg. I did not learn German since I dedicated most of my time to my law studies and my children and spent more time in Spain than in Germany due to my studies. My marriage itself didn't add any difficulties to my studies, but having children made it a little more difficult for me. However, I was the one that insisted in wanting to be a young mother in order to enjoy better my children; this didn't work out exactly like I wanted; when I was with the kids I couldn't really enjoy it due to the stress in which I was nearly always in, I just kept thinking about all the subjects I had to study and when I was studying I had a guilty conscience that I didn't give the children enough time. However, with stress, hard work and tears every now and then, I managed to finish my Law Degree, in Spain, and worked there as a lawyer for three years. I also specialized in Public and Private International Law.

I did all this before that my first child, who was already in kindergarten, started his first school year, because I knew that our mobility would be limited when he started school. When our first child was nearly turning six years old I decided to finish my work in Spain, study German and work in Freiburg. Just after I took this decision, my husband had an attractive offer to build and be head of the radiology department in a private hospital in Amman, Jordan. So we all moved to Jordan and my eldest son started his first school year in an international, Arabic/English, school in Amman.

In Jordan I worked in different research groups that have to do with various themes, specially: women rights, child 